\title{
ASSESSMENT OF LEARNING FOR INFORMATION LITERATION COURSE USING THE SOCRATIVE APPLICATION
}

\author{
Inawati $^{1}$ \\ Nidya Desyana ${ }^{2}$ \\ Universitas Negeri Malang, Indonesia ${ }^{1,2}$ \\ $\underline{\text { inawati.fs@um.ac.id }}^{1}$, nidya.desyana.1803218@students.um.ac.id ${ }^{2}$
}

\begin{abstract}
The era of industrial revolution 4.0 is marked by the development of very fast and unlimited information so that education has a very important role. Along with these developments, it is necessary to develop a new paradigm in the world of education, namely using a touch of technology in carrying out learning assessments, one application that can be used is the Socrative application which can be used by teachers in providing feedback on student work. The purpose of this study was to describe the practicality of using the Socrative application as a media assessment of learning in the Information Literacy course with 18 students as respondents. The average percentage result of all indicators during the trial period was $58.8 \%$ who considered it feasible and practical to use the Socritive application when carrying out the assessment of learning.
\end{abstract}

Keywords: Assessment of Learning; Socritive Application; Information Literacy

\section{INTRODUCTION}

The development of industry 4.0 is marked by the rapid development of information from various aspects of science. With the amount of information available, good literacy skills are needed ${ }^{1}$. Good literacy skills can be obtained by examining components including media literacy, culture, digital, technology and others ${ }^{2}$. In response to this, Indonesia has begun to apply information literacy at the school level ${ }^{3}$.

Information literacy is the ability to carry out knowledge management and the ability to learn continuously. The benefits of information literacy are helping students produce new quality knowledge for themselves and their surroundings, assisting students in solving problems starting from the problem identification stage to the evaluation stage, and determining the solution to a problem.

Information literacy skills are needed by librarians so that information literacy courses are included in the library science study program curriculum. To measure students' understanding of these subjects, an assessment is needed. Assessment is the process of collecting information about knowledge, attitudes / behaviors, and

\footnotetext{
1 Oviolanda Febrianti, Lifia Yola Putri \& Irianto, "Pentingnya Penguasaan Literasi Bagi Generasi Muda Dalam Menghadapi Mea," 2017, 640-47, http://jurnal.unissula.ac.id/index.php/ELIC/article/view/1282.

${ }^{2}$ Dikdasmen KEMENDIKBUD, Buku Saku Gerakan Literasi Sekolah, Dikdasmen Kementerian Pendidikan Dan Kebudayaan, 2018.

3 Aulia Akbar, "Membudayakan Literasi Dengan Program 6M Di Sekolah Dasar," Jurnal Pendidikan Sekolah Dasar 3, no. 1 (2017).
} 
individual and group skills through a learning process that can be used in decision making. The main purpose of assessment is to improve the quality of education because it can be used as a benchmark for learning outcomes ${ }^{4}$. One of the assessments that can be applied to the learning process is assessment of learning.

Assessment of learning is an assessment with a summative purpose ${ }^{5}$. This assessment is designed to provide an overview of each student's knowledge. The results of the assessment are useful for the teaching staff in determining the extent to which students understand the concepts, while for students the assessment is useful as feedback on their understanding ${ }^{6}$. In addition, student behavior can be influenced by assessments conducted by teaching staff ${ }^{7}$.

Assessment of learning is carried out at the end of the lesson or based on the basic competition to be achieved. This assessment is generally carried out by means of a paper and pecil test with the duration of the question processing including all the question numbers. Paper and pencil tests cannot limit the duration of working on each question number so that technology needs to be used in learning to overcome this.

The use of technology in learning has been widely carried out in the fields of science, applied science, humanities and other scientific subjects. Examples are the use of schoology in science ${ }^{8}$, the use of edmodo in the humanities ${ }^{9}$, a combination of Google SketchUp and Ispring Suite 8 in mathematics learning ${ }^{10}$, and others. Besides being used in the teaching and learning process, technology can also be used in conducting assessments. As for the e-learning media used in carrying out assessments in the Information literacy course for Diploma III Mahasiswa Perpustakaan, it is known as a social application. Socrative is an application that can be used to measure students' abilities in learning evaluation.

\section{THEORITICAL REVIEW}

The Socrative application can be used on smartphones and personal computers (PC). Its use on smartphones makes the application wider and easier to use the

${ }^{4}$ Dewi Mardhiyana and J Jailani, "Pengembangan Model Asesmen Pembelajaran Matematika SMA Berdasarkan Kurikulum 2013 Developing of Assessment Model of Mathematics Learning in Senior High School Based On Curriculum 2013," PYTHAGORAS: Jurnal Pendidikan Matematika 12, no. 2 (2017): 135-48.

5 Stephen Boyle, James \& Fisher, "Review of 'Educational Testing: A Competence Based Approach," In The British Psychological Society and Blackwell Publishing Ltd, 2007, https://rune.une.edu.au/web/handle/1959.11/15779.

${ }^{6}$ Wiwi. Gebi Dwiyanti. Cahya Gumilar Siswaningsih, "Penerapan Peer Assessment Dan Self Assessment Pada Tes Formatif Hidrokarbon Untuk Feedback Siswa SMA Kelas X," Jurnal Pengajaran MIPA 18 (2013): 107-15.

7 Christopher J. Watling and Shiphra Ginsburg, "Assessment, Feedback and the Alchemy of Learning," Medical Education 53, no. 1 (2019): 76-85, https://doi.org/10.1111/medu.13645.

8 Zelin Norma Resty, Muhardjito Muhardjito, and Nandang Mufti, "Discovery Learning Berbantuan Schoology: Upaya Peningkatan Kemampuan Berpikir Kritis," Jurnal Pendidikan: Teori, Penelitian, Dan Pengembangan 4, no. 2 (2019): 267-73, https://doi.org/10.17977/JPTPP.V4I2.12040.

9 Marko Wibisono, Franciska Maria Ivone, and Enny Irawati, "Students ' Reading Comprehension for Eleventh Graders" 7, no. 1 (2019): 16-25.

${ }^{10}$ Ani Nurwijayanti, Budiyono, and Laila Fitriana, "Combining Google Sketchup and Ispring Suite 8: A Breakthrough to Develop Geometry Learning Media," Journal on Mathematics Education 10, no. 1 (2019): 103-15, https://doi.org/10.22342/jme.10.1.5380.103-116. 
application. The Socrative application is divided into two, namely the student application and the teacher application.

The social student application is an application that students can use to connect to the application used by the teaching staff in conducting assessments. Students use the socrative application by filling in the name of the room that will be used by the teaching staff. The name of the room is obtained from the social teacher application which can only be accessed by lecturers.

The social teacher application is an application used by teaching staff (lecturers) in conducting assessments. The initial appearance of the social teacher application consists of the email and password used when creating the account and must be filled in to gain access to the room that is owned. First, the teaching staff creates an account inorder to get a room ID. The ID room is given to students so that they can join the room that has been made by the teaching staff, then the students carry out tests on their respective social student applications. Second, if the teaching staff has logged in, there are six activity options which are divided into two categories, namely test implementation and test making. The test implementation category is divided into three menus, namely (1) Quiz to carry out the test, (2) space race to do the test in groups, and (3) Exit ticket which is used to evaluate the quiz.

Meanwhile, in the test-making category, there are three forms of tests that can be made, namely (1) Multiple Choice to make multiple choice questions, (2) True or False to make questions true or false, and (3) Short Answer to make questions in the form of a short answer. If the quiz has been created, the next step is to release the quiz that has been created. In this menu, there are several additional settings, such as require names, shuffle answers, show question feedback, and show final score.

This additional arrangement can make it easier for teachers to see the final results of each student's test. The assessmant results of each student can be seen in the report menu which can be identified by color in the report table. The red table indicates the student is wrong in answering the question, the white table indicates the student did not answer the question number and the green table shows the student answered the question correctly. In addition, there is also a percentage of student answers that are correct. a summary of the overall answer results of students who took the test by identifying the number of students who answered correctly or wrongly. The test results can be downloaded in the form of a file, making it easier for the teaching staff to identify the student's answer choices for each question item.

The use of technology in conducting assessment has its own advantages in the world of education. This is in line with a research conducted by Pakpahan, Rogers with the title Computer Based National Exam Model: Its Benefits and Barriers, which concluded that computer-based assessments can save costs, be more effective and make the scoring process easier. ${ }^{11}$ One application that can be used to conduct an assessment is the Socrative Application. Learning research using Socrative Application has been carried out in the scientific field of pharmacy with the title The Use of Socrative and Yammer Online Tools to Promote Interactive Learning in

\footnotetext{
${ }^{11}$ Rogers Pakpahan, “Computer Based National Exam Model: Its Benefits and Barriers,” Jurnal $\begin{array}{lllllll}\text { Pendidikan Dan } & \text { Kebudayaan } & \text { 1, } & \text { no. } & 1 & \text { (2016): }\end{array}$ https://media.neliti.com/media/publications/124980-none-a7dd8e51.pdf.
} 
Pharmacy Education ${ }^{12}$, in Physics the title Using Socrative Software for Instant Formative Feedback in Physics Courses ${ }^{13}$, in chemistry under the title Effectiveness of Mobile Devices as Audience Response Systems in the Chemistry Laboratory Classroom $^{14}$ and other scientific sub-fields. However, the use of the Socrative Application at the tertiary level, especially in the subject of information literacy, is still rare. Therefore, the use of technology in conducting assessments must be studied more.

\section{RESEARCH METHODOLOGY}

This research is descriptive research. The purpose of this study is to describe the practicality of socrative as an assessment of learning. The practicality test was carried out by giving a questionnaire to 18 students who were taking the Information Literacy course for the Diploma III Library Study Program. The questionnaire used contains 10 questions which are grouped into categories, instructions for using the application, application design, convenience, reability and the form of question presentation. The scale used is a Likert scale, then the results obtained are made in percentage form and categorized in the form of intervals. Categories or criteria for interactive multimedia practicality can be seen in the following table:

Tablel 2.

Criteria for Interactive Multimedia Practicality ${ }^{15}$

\begin{tabular}{lll}
\hline Criteria (\%) & Categories & Information \\
\hline $75,01-100,00$ & Very Practical & Can be used without revision \\
\hline $50,01-75,00$ & Practical & Can be used with minor revisions \\
\hline $25,01-50,00$ & Less Practical & Recommended for use \\
\hline $00,00-25,00$ & Impractical & Cannot be used \\
\hline & (Sumber: Diadaptasi dari Akbar, 2011: 208)
\end{tabular}

\section{IV.RESULTS OF RESEARCH AND DISCUSSION}

Simple survey results by spreading instruments in the form of questionnaires after the middle semester assessment activity is conducted on the subject of information literacy by using one of the e-learning applications in the learning form of socritive application. Data Collection consists of several assessment indicators conducted by respondents, among others, application instructions, media display, ease

12 Shankar Munusamy et al., "The Use of Socrative and Yammer Online Tools to Promote Interactive Learning in Pharmacy Education," Currents in Pharmacy Teaching and Learning 11, no. 1 (2019): 76-80, https://doi.org/10.1016/j.cptl.2018.09.021.

${ }^{13}$ Nuri Balta and Katerina Tzafilkou, "Using Socrative Software for Instant Formative Feedback in Physics Courses," Education and Information Technologies 24, no. 1 (2019): 307-23, https://doi.org/10.1007/s10639-018-9773-8.

${ }^{14}$ Jenifer Santos et al., "Effectiveness of Mobile Devices as Audience Response Systems in the Chemistry Laboratory Classroom," Computer Applications in Engineering Education 27, no. 3 (2019): 572-79, https://doi.org/10.1002/cae.22098.

15 Maharani Putri Kumalasani, "Kepraktisan Penggunaan Multimedia Interaktif Pada Pembelajaran Tematik Kelas IV SD," Jurnal Bidang Pendidikan Dasar 2, no. 1A (2018): 1-11, https://doi.org/10.21067/jbpd.v2i1a.2345. 
of access, presentation form, and time of work. From the indicators are obtained data analysis results in the form of a percentage value as follows.

Firstly, for the availability of the application manual is acquired by $66.7 \%$ of respondents stating that the media usage instructions are easy to understand, $27.8 \%$ of the respondents stating the application is very easy to understand, 5.5\% of the respondents stating it is quite easy to understand and no one who says is difficult to understand. It proves that the app is easy to use.

Secondly, the e-learning Learning Media display has an important role in giving the user an appeal. Socritive application is one of the e-learning learning media used. To see the level of the students ' levels in terms of images, colors and graphics, can be seen from the percentage of data analysis results that is $72.2 \%$ of respondents who expressed interesting, $22.2 \%$ that considered very interesting, $5.6 \%$ of respondents who expressed interesting enough and no one respondent stating that the application is not interesting in terms of images, colors and graphics.

Thirdly, ease in understanding and use the application during the assessment process is implemented using one of e-learning application is socritive application based on the results of analysis of data obtained by $44.4 \%$ of respondents stating that with socritive application makes it easy for respondents to respond to exam questions, $27.8 \%$ of respondents who consider the socritive application quite easier in answering the problem, the $22.2 \%$ of respondents who consider using socritive application is very easy to do/answer test questions, and $5.6 \%$ of respondents who feel this application is less helpful in working on the problem. From the results of this ananlysis it can be interpreted that by using socritive application greatly facilitate the respondent in carrying out the assessment.

Fourth, it is undeniable that the form of the problem presented must be in accordance with the menu in the e-Learning Media that is used so that it will support the achievement of learning objectives. As for the response from the respondent related to the presentation of the form given based on the percentage of data analysis results is $61.1 \%$ of respondents who replied that the presentation about using socritive application is simple and easy to understand, $22.2 \%$ of respondents who stated quite simply, $16.7 \%$ of respondents who said is very simple and very easy to understand, and none of the respondents who find it difficult.

Fifth, in addition to the above several indicators, then to see the practicality of an e-learning media in carrying out the assessment should we see how the time management is available. In terms of suitability timing of the problem with the schedule of assessment implementation obtained percentage of data analysis results of $50 \%$ of respondents who replied that the time management in the work of the problem according to the needs of respondents, $33.3 \%$ of respondents who answered well enough, the $11.1 \%$ Respondenn answer was less appropriate, and 5.6\% of respondents who replied that the time in the work of the problem fits perfectly with the needs of the respondent and not any respondent who feels not in accordance with the needs of the respondent in terms of working time.

The use of socrative application for ssessment of learning in Information Literacy course is conducted during midterm exam to measure student comprehension level. The test is made in the form of multiple choice with the number of questions as many as twenty grains. Each student has the same time to answer the test questions that have been made with a duration of 90 seconds each question number. 
To answer the questions, students can use the socrative application which is based on Android or by using a web browser so as to reduce student opportunities to cooperate in answering test questions, Mengefesienkan time used in the assessment, and directly give a feadback to the student's answer. In addition, using this application can minimize the cost used to perform the assessment.

The practical test of the application socrative in carrying out the assessment has been conducted on the student Prodi Diploma III Library Universitas Negeri Malang that went through the course of information literacy. Results obtained from the use of socrative application in carrying out assessment of learning entry in practical category and worthy to be used as assessment of learning on the subject of information literacy with an average percentage of overall indicator of $58.88 \%$, this is in line with previous research that concluded that with the use of socrative application can give lecturers easy to interact quickly and easily thus giving a better learning experience to ${ }^{16}$

\section{CONCLUSION}

Based on the results of the analysis, it can be concluded that the use of the socrative Application to implement assessment of learning in the information literacy course can support the assessment process. The excess assessment of learning using the socrative Application is time efficiency, minimizing costs, providing assessments in real time, as well as reducing the possibility of cooperation in answering the problem/quiz. In addition, the assessment can be known directly by lecturers and students in the form of report files in the Reports menu reports, so that with the many advantages that exist then the use of socrive application is considered paraktis in conducting assessment.

\section{REFERENCE}

Akbar, Aulia. "Membudayakan Literasi Dengan Program 6M Di Sekolah Dasar." Jurnal Pendidikan Sekolah Dasar 3, no. 1 (2017).

Balta, Nuri, and Katerina Tzafilkou. "Using Socrative Software for Instant Formative Feedback in Physics Courses." Education and Information Technologies 24, no. 1 (2019): 307-23. https://doi.org/10.1007/s10639-018-9773-8.

Boyle, James \& Fisher, Stephen. "Review of 'Educational Testing: A Competence Based Approach." In The British Psychological Society and Blackwell Publishing Ltd, 2007. https://rune.une.edu.au/web/handle/1959.11/15779.

Dervan, Paul. "Enhancing In-Class Student Engagement Using Socrative (an Online Student Response System): A Report." The All Ireland Journal of Teaching \&

${ }^{16}$ Paul Dervan, "Enhancing In-Class Student Engagement Using Socrative (an Online Student Response System): A Report.," The All Ireland Journal of Teaching \& Learning in Higher 6, no. 2 (2014): 1977, http://ojs.aishe.org/aishe/index.php/aishe-j/article/view/180/283\#. 
Learning in Higher 6, no. $2 \quad$ (2014): 1977. http://ojs.aishe.org/aishe/index.php/aishe-j/article/view/180/28̌3.

Febrianti, Lifia Yola Putri \& Irianto, Oviolanda. "Pentingnya Penguasaan Literasi Bagi Generasi Muda Dalam Menghadapi Mea," 2017, 640-47. http://jurnal.unissula.ac.id/index.php/ELIC/article/view/1282.

KEMENDIKBUD, Dikdasmen. Buku Saku Gerakan Literasi Sekolah. Dikdasmen Kementerian Pendidikan Dan Kebudayaan, 2018.

Kumalasani, Maharani Putri. "Kepraktisan Penggunaan Multimedia Interaktif Pada Pembelajaran Tematik Kelas IV SD.” Jurnal Bidang Pendidikan Dasar 2, no. 1A (2018): 1-11. https://doi.org/10.21067/jbpd.v2i1a.2345.

Mardhiyana, Dewi, and J Jailani. "Pengembangan Model Asesmen Pembelajaran Matematika SMA Berdasarkan Kurikulum 2013 Developing of Assessment Model of Mathematics Learning in Senior High School Based On Curriculum 2013." PYTHAGORAS: Jurnal Pendidikan Matematika 12, no. 2 (2017): 13548.

Munusamy, Shankar, Aisha Osman, Sadaf Riaz, Shaima Ali, and Fatima Mraiche. "The Use of Socrative and Yammer Online Tools to Promote Interactive Learning in Pharmacy Education." Currents in Pharmacy Teaching and Learning 11, no. 1 (2019): 76-80. https://doi.org/10.1016/j.cptl.2018.09.021.

Nurwijayanti, Ani, Budiyono, and Laila Fitriana. "Combining Google Sketchup and Ispring Suite 8: A Breakthrough to Develop Geometry Learning Media." Journal on Mathematics Education 10, no. 1 (2019): 103-15. https://doi.org/10.22342/jme.10.1.5380.103-116.

Pakpahan, Rogers. "Computer Based National Exam Model: Its Benefits and Barriers." Jurnal Pendidikan Dan Kebudayaan 1, no. 1 (2016): 19-35. https://media.neliti.com/media/publications/124980-none-a7dd8e51.pdf.

Resty, Zelin Norma, Muhardjito Muhardjito, and Nandang Mufti. "Discovery Learning Berbantuan Schoology: Upaya Peningkatan Kemampuan Berpikir Kritis." Jurnal Pendidikan: Teori, Penelitian, Dan Pengembangan 4, no. 2 (2019): 26773. https://doi.org/10.17977/JPTPP.V4I2.12040.

Santos, Jenifer, Luisa Parody, Manuel Ceballos, María C. Alfaro, and Luis A. TrujilloCayado. "Effectiveness of Mobile Devices as Audience Response Systems in the Chemistry Laboratory Classroom." Computer Applications in Engineering Education 27, no. 3 (2019): 572-79. https://doi.org/10.1002/cae.22098.

Siswaningsih, Wiwi. Gebi Dwiyanti. Cahya Gumilar. "Penerapan Peer Assessment Dan Self Assessment Pada Tes Formatif Hidrokarbon Untuk Feedback Siswa SMA Kelas X.” Jurnal Pengajaran MIPA 18 (2013): 107-15.

Watling, Christopher J., and Shiphra Ginsburg. "Assessment, Feedback and the Alchemy of Learning." Medical Education 53, no. 1 (2019): 76-85. https://doi.org/10.1111/medu.13645.

Wibisono, Marko, Franciska Maria Ivone, and Enny Irawati. "Students ' Reading Comprehension for Eleventh Graders" 7, no. 1 (2019): 16-25. 